\title{
Effects of p-Coumaric Acid on Ruminal Fermentation Parameters in In Vitro Ruminal Cultures
}

\author{
Mihaela GIUBURUNCĂ $\breve{A}^{*}$ Adriana CRISTE, Vioara MIREŞAN \\ University of Agricultural Sciences and Veterinary Medicine, Faculty of Animal Science and \\ Biotechnologies, 3-5 Mănăștur Street, 400372 Cluj-Napoca, Romania \\ *Corresponding author, email: mihaela.giuburunca@gmail.com.
}

Bulletin UASVM Animal Science and Biotechnologies 72(1) / 2015

Print ISSN 1843-5262; Electronic ISSN 1843-536X

DOI:10.15835/buasvmcn-asb:10684

\begin{abstract}
Enteric fermentation from ruminants represents, besides the contribution to global warming, a huge energy loss for the animal. To reduce the methane emissions and to increase livestock productions (milk or meat), many researchers initiated some attempts such as defaunation process, uses of chemicals additives, ionophore antibiotics, plant extracts or diet changes. The major aim of this study was to evaluate the effects of one plant extract, in form of a plant secondary metabolite, the p-Coumaric acid in $6 \mathrm{mM}$ concentration on ruminal parameters in vitro. The fermentation parameters were measured after 24, 48 and 72 hours of incubation. p-Coumaric acid addition in $6 \mathrm{mM}$ concentration showed promising effects in decreasing ruminal methane emissions without affecting the other ruminal fermentations parameters.
\end{abstract}

Keywords: in vitro, fermentation, methane, ruminal cultures

\section{INTRODUCTION}

Under anaerobic conditions, the ruminal digestion of feed by the microorganisms, results in the production of volatile fatty acids, which are used by the animal as energy source, and the production of ruminal gases: hydrogen, carbon dioxide and methane, which are eliminated through eructation (Eugène et al., 2008). Besides its negative impact on the environment, ruminal methanogenesis represents a loss of $2-15 \%$ of gross energy intake (Garcia et al., 2006) for the animal. The major aim of the most researchers in this field was to reduce methane emissions and to improve the efficiency of ruminant production in an ecologically and sustainable way. A new, safe and inexpensive way to reduce methane emission from ruminants is the use of plant extracts, such as polyphenols, tannins or saponins.

\section{AIMS AND OBJECTIVES}

The aim of this study was to evaluate the effects of one plant extract, in form of a plant secondary metabolite, the p-Coumaric acid in $6 \mathrm{mM}$ concentration on ruminal parameters in vitro. The fermentation parameters were measured after 24, 48 and 72 hours of incubation.

\section{MATERIALS AND METHODS}

p-Coumaric acid was added anaerobically in a $6 \mathrm{mM}$ concentration to $100 \mathrm{ml}$ serum bottles containing $0.50 \mathrm{~g}$ alfalfa hay as a substrate, 10 $\mathrm{ml}$ rumen fluid collected from a fistulated sheep before morning feeding, and $40 \mathrm{ml}$ of 141 culture medium for Methanogens microorganisms (DSMZ). The bottles were sealed and incubated at $39^{\circ} \mathrm{C}$. Fermentation parameters that were measured are the following: total gas volume, methane production (measured with Gas-Chromatography method), acetate, propionate, n-Butyrate, isoButyrate and iso-Valerate concentrations (with High Performance Liquid Chromatography).

\section{RESULTS AND DISCUSSION}

Results showed that after 24 hours of incubation, p-Coumaric acid decreased significantly the total gas volume $(p \leq 0.05)$ and 
Tab. 1. Effects of p-Coumaric acid on rumen fermentation parameters in vitro after 24,48 and $72 \mathrm{~h}$ incubation

\begin{tabular}{|c|c|c|c|c|c|c|}
\hline \multirow{5}{*}{$\begin{array}{c}\text { Gas volume } \\
(\mathrm{ml} / 100 \mathrm{ml})\end{array}$} & \multicolumn{2}{|c|}{24} & \multicolumn{2}{|c|}{48} & \multicolumn{2}{|c|}{72} \\
\hline & Control & $\begin{array}{l}\text { p-Cumaric } \\
\text { acid } 6 \mathrm{mM}\end{array}$ & & $\begin{array}{l}\text { p-Cumaric } \\
\text { acid } 6 \mathrm{mM}\end{array}$ & & $\begin{array}{l}\text { p-Cumaric } \\
\text { acid } 6 \mathrm{mM}\end{array}$ \\
\hline & 36.17 & 33.20 & 76.80 & 69.01 & 60.79 & 52.51 \\
\hline & \pm 0.34 & \pm 0.45 & \pm 0.40 & \pm 1.32 & \pm 0.15 & \pm 1.07 \\
\hline & - & $* *$ & - & $* * *$ & - & $* * *$ \\
\hline & 2.46 & 2.22 & 7.11 & 5.75 & 8.38 & 8.12 \\
\hline $100 \mathrm{ml}$ ) & \pm 0.18 & \pm 0.06 & \pm 0.23 & \pm 0.46 & \pm 0.64 & \pm 0.81 \\
\hline & - & - & - & - & - & 7 \\
\hline Acetate & $\begin{array}{l}1769.31 \\
\pm 15.68\end{array}$ & $\begin{array}{l}1745.69 \\
\pm 20.55\end{array}$ & $\begin{array}{c}2185.69 \\
\pm 39.99\end{array}$ & $\begin{array}{l}2160.28 \\
\pm 14.58\end{array}$ & $\begin{array}{l}2334.39 \\
\pm 26.33\end{array}$ & $\begin{array}{l}2377.82 \\
\pm 16.36\end{array}$ \\
\hline & - & - & - & $=$ & - & - \\
\hline Propionate & 655.30 & 565.44 & 623.05 & 687.77 & 661.14 & 747.40 \\
\hline $\begin{array}{l}\text { Propionate } \\
\text { (mg/L) }\end{array}$ & $\begin{array}{c} \pm 14.91 \\
-\end{array}$ & $\begin{array}{c} \pm 12.49 \\
* *\end{array}$ & $\begin{array}{c}28.97 \\
-\end{array}$ & \pm 25.12 & $\begin{array}{c}12.80 \\
-\end{array}$ & $\begin{array}{c} \pm 27.35 \\
*\end{array}$ \\
\hline $\begin{array}{c}\text { n-Butyrate } \\
\text { (mg/L) }\end{array}$ & $\begin{array}{c}568.40 \\
\pm 20.91 \\
-\end{array}$ & $\begin{array}{r}552.78 \\
\pm 25.14\end{array}$ & $\begin{array}{r}633.21 \\
\pm 17.07\end{array}$ & $\begin{array}{r}679.47 \\
\pm 30.58\end{array}$ & $\begin{array}{c}583.58 \\
\pm 3.78\end{array}$ & $\begin{array}{c}630.07 \\
\pm 3.77\end{array}$ \\
\hline $\begin{array}{c}\text { iso-Butyrate } \\
(\mathrm{mg} / \mathrm{L})\end{array}$ & $\begin{array}{c}31.51 \\
\pm 5.48 \\
-\end{array}$ & $\begin{array}{c}20.72 \\
\pm 0.82 \\
-\end{array}$ & $\begin{array}{c}151.27 \\
\pm 1.03 \\
-\end{array}$ & $\begin{array}{c}141.73 \\
0.07 \\
* * *\end{array}$ & $\begin{array}{c}10 \overline{9} .46 \\
\pm 0.72\end{array}$ & $\begin{array}{c}108.11 \\
\pm 5.51\end{array}$ \\
\hline $\begin{array}{l}\text { iso-Valerate } \\
(\mathrm{mg} / \mathrm{L})\end{array}$ & $\begin{array}{c}59.83 \\
\pm 8.95 \\
-\end{array}$ & $\begin{array}{c}54.26 \\
\pm 0.13 \\
-\end{array}$ & $\begin{array}{c}243.66 \\
\pm 16.26 \\
-\end{array}$ & $\begin{array}{c}204.01 \\
\pm 8.46 \\
-\end{array}$ & $\begin{array}{c}230.45 \\
\pm 14.14 \\
-\end{array}$ & $\begin{array}{c}202.20 \\
\pm 9.80 \\
-\end{array}$ \\
\hline
\end{tabular}

the propionate production (Tab. 1). The other parameters were not affected by this plant extract. At 48 hours, it was observed the same decreased in total gas volume results $(\mathrm{p} \leq 0.05)$ and also a decrease tendency in methane production, but not significantly $(\mathrm{p}=0.058)$. The other parameters were not affected significantly. After 72 hours of incubation, p-Coumaric acid decreased total gas volume $(p \leq 0.05)$ and increased the propionate production $(\mathrm{p} \leq 0.05)$. Methane emissions and the other parameters were not affected. It was demonstrated that addition of p-Coumaric acid had an inhibition effect on rumen microorganisms such as R. albus and R. flavefaciens (Varel and Jung, 1986) and this effect depended on the applied concentration. Jayanegara (2009) used this extract against rumen methanogens and the results showed that after 24 hours, p-Coumaric acid added in $5 \mathrm{mM}$ decreased methane production and also decreased propionate concentration. Rumen microbes can adapt and can present defense mechanisms against phenolic acids (Jayanegara, 2009). This might explain the fluctuation in results during the entire experiment time (72 hours). Also, phenolic acids can be released via cell wall degradation, which can affect their inhibitory ability.

\section{CONCLUSION}

p-Coumaric acid addition in $6 \mathrm{mM}$ concentration showed an decrease in propionate concentration and total gas volume after 24 hours of incubation. After 48 hours, it was observed a difference in iso-Butyrate concentration. The effect of p-Coumaric on rumen fermentation parameters after 72 hours is lost, except the total gas volume.

\section{REFERENCES}

1. Eugène M, Massé D, Chiquette J and Benchaar C (2008). Meta-analysis on the effects of lipid supplementation on methane production in lactating dairy cows, Canadian J. Anim. Sci. 88, 331-334.

2. Garcia-Gonzáles R, López S, Fernández M and Gonzáles JS (2006). Effects of the addition of some medicinal plants on methane production in a rumen simulating fermenter (RUSITEC), Int. Congr. Ser. 1293, 172-175.

3. Jayanegara A. (2009). Ruminal methane production on simple phenolic acids addition in in vitro gas production method, Media Peternakan, 32/1, 53-62.

4. Varel GH and Jung HJG (1986). Influence of forage phenolics on ruminal fibrolytic bacteria and in vitro fiber degradation, Appl. Environ. Microbiol. 52, 275-280. 